EJAE 2017, 14(2): 19-30

ISSN 2406-2588

UDK: 330.101 .54

336.563:331.5(540)

DOI: 10.5937/ejae14-14311

Original paper/Originalni naučni rad

\title{
DOES SHG PROGRAM ALLEVIATE POVERTY? EVIDENCE FROM FOUR CLUSTERS IN SEMI-URBAN REGIONS OF INDIA
}

\author{
Sivagandhi Saravanan* \\ Madras School of Economics, \\ Chennai, Tamil Nadu, India
}

\begin{abstract}
:
The paper suggests that microfinance program has significantly improved the standard of living of the poor people. The datasets from 367 SHG members and 178 non-SHG members are taken into analysis. Simultaneous equation method is applied to observe the effect of exogenous variables on the endogenous variable. Income and asset are endogenous variables, which have significant impacts on each other. Age, education and village infrastructure have positive impacts on both income and asset.
\end{abstract}

\section{Keywords:}

poverty, microfinance, control, treatment, simultaneous equation.

\section{INTRODUCTION}

According to the World Bank, out of five Indians one is poor i.e. 270 million people are below the poverty line. The India's Poverty Profile released by the World Bank highlights that $80 \%$ of India's poor people live in rural areas (World Bank, 2016). Generally, the section of population that is economically or socially underprivileged cannot meet the basic needs. This in turn results in higher unemployment, poor health standards, and lesser labour productivity that results in lesser economic development and creates social unrest. Microfinance, which came into existence in the 1970s and emerged as a panacea to the poor, provided access of credit facilities to the population in target. It is broadly defined as the provision of credit and other financial services to the underprivileged, who are usually low-income individuals working in the informal economy and unbankables (Armendariz \& Morduch, 2005; Ledgerwood \& Gibson, 2013). MFIs are operating at large level in the third world countries where the financial penetration rates are low compared to developed economies, and are low and middle income communities (Chiu, 2017). Microfinance flows into emerging economies through various channels: MFIs, NBFIs, SHGs, the cooperatives and state level banks (Ledgerwood \& Gibson, 2013). The practice of microfinance dates back to the rural financial scenario without popularity and became popular after the commercialization of the sector (Fuchs, 2006; Maes \& Reed, 2012). By involving in formal banking activities, MFIs do not depend on donations and subsidies (Cull et al, 2009; Earne \& Sherk, 2013). On the beneficiary's part, microfinance helps them start up or enhance microenterprise 
activities, consumption smoothing, empowerment and financial systems development through collateral support (Dunford, 2006; Van Rooyen, Stewart \& De Wet, 2012). According to Simanotwitz \& Walter (2002), conventional banks are reluctant to provide small loans to the unbankables based on the assumption that the repayment capacity and collateral security of the unbankables are either minimal or zero. Today, microfinance is not limited to the provision of microcredit but is also inclusive of short term financial service for those who are excluded by the traditional formal sources. It is disheartening to note that about 4.5 billion of the world's population, having low and lower incomes, does not have access to formal financial services (Dichter \& Harper, 2007).

Microfinance plays a critical role in overcoming unexpected shocks such as illness or death of a wage earner(s), climate shocks which cause considerable losses to poor and large indebtedness. The effects of microcredit programs on poverty alleviation are still a debatable issue, but the world development organization acclaim microfinance as a major solution for the eradication of the world's poverty. It is really important to carry out a detailed and in-depth analysis of the impact of microfinance programs in the developing countries. Similarly, it is also important to provide answers to the controversy. The present study examines the effects of microfinance on the socio-economic variables and poverty alleviation on the sample of population from a semi-urban region of India, in the state of Tamil Nadu. We have selected clusters of villages of district Tiruvallur as a case study to determine whether enrolment in microfinance activities enhances the income level of the sample. This work follows a control-treatment approach for a comparison purpose. The empirical result of this work indicates that microfinance can help in enhancing the income level of the sample in particular and hence the population in general.

\section{REVIEW OF THE SELECT LITERATURE}

After the advent of the Microfinance concept, numerous studies were carried out and two interesting and surprising findings emerged. One group of researchers found that microfinance is a powerful weapon on poverty indicators and other group denied the fact. The outcomes of microfinance are many: some authors found that microfinance alleviates poverty (Hulme \& Mosley, 1996; Pitt \& Khandker, 1998; Copestake, 2002; Galab \& Chandrasekhar Rao, 2003; Khandker, 2005; Tedeschi, 2010); women empowerment (Hashemi et al, 1996; Goetz \& Sengupta, 1996; Steele et al, 1998; Morduch, 1999; Rahman et al, 2009; Pitt et al, 2006; Garikipati, 2012; Saravanan \& Prasad, 2017) and impact on education, health, nutrition, consumption level and assets creation (Hazarkia \& Sarangi, 2008; Gertler et al, 2006; Jacobsen, 2009; Kouassi, 2008; Leatherman et al, 2012; Deloach \& Lamanna, 2011). A significant contribution of the study is that it includes the variable village infrastructure as one of parameters to examine the impact of microfinance. Village infrastructure does not play a decisive role in the context that the members' accruing income may be the result of economic growth rather than microfinance. Therefore, the variable has been taken into account in the 2SLS technique. The village infrastructure index is composed of the road-railway connectivity, presence of Primary Health Care Centre (PHC), Higher Education Institutions, and industries. The literature review provides a clear insight into the impact of microfinance on indicators of poverty. The study examines income and asset creation. Furthermore, the study tries to find out the answers to the following questions: (1) Does microfinance through SHGs really have positive impacts on poverty indicators, and (2) whether microfinance is really a cause of income change or overall economic growth of the region. 


\section{SAMPLE SELECTION AND METHOD}

The NABARD (National Bank for Agriculture and Rural Development), an apex bank for rural development, framed detailed guidelines for starting and nurturing up of SHGs. The guideline clearly stated that an SHG can be linked to bank loans only after a group has actively existed for about six months (NABARD, 1999). Following the NABARD norms, we adopt multistage random sampling technique for sample selection survey. This study compares the impact of microfinance on Self-Help Group (SHG) members vis-a-vis non-members. The non-members of this study are those who never self-select to participate in the self-help group, but belong to same locality. Tiruvallur district was randomly chosen for the evaluation study, a cluster of four blocks namely Tiruvallur, Tiruttani, Gummudipoondi and Ponneri which fall under Tiruvallur District has been selected. They comprise more than 1,500 SHG members. The sample respondents have been chosen at random from the list of members available from Tamil Nadu Women Development Corporation office at the headquarters of Tiruvallur District. The non-members data have been collected from the same cohort to make an absolute comparison. The dataset for the study has been collected through a primary survey of 545 respondents, by using a semi-structured questionnaire during 2010. The questionnaire comprises questions related to social, economic parameters of households along with the microfinance activities. From the sample, 367 respondents were members of SHGs and 178 respondents were non-members. The primary data collected were processed for data analysis using standard statistical tools such as percentage, test of equality of mean. Furthermore, an econometric tool such as the two stage least square method (2SLS) is applied to arrive at the determinants of income and asset at the household level.

\section{EMPIRICAL FINDINGS}

\section{Descriptive Analysis}

To measure the level of poverty, different indicators are used. Some economists argued that income is the best indicator to measure. Others negated it and asserted that consumption expenditure is an alternative measurement of poverty. Poverty was traditionally viewed as a lack of income to acquire basic necessities of life. Now, poverty has been measured through various indicators such as, consumption expenditure, nutritional status, capability etc. In the study, income is considered to be one of the main determinants of poverty, since income is an immediate result of economic activity. The increasing level of income would lead to more consumption expenditures which result in a better standard of living. The Microfinance program makes the beneficiaries economically more powerful; SHGs program turns the members to possess productive assets that leads to incremented income and employment which helps them to overcome the clutches of poverty and vulnerable situation. The study discusses the differences in the individual and household earnings of the members. We discuss the impact of microfinance through change in income level between treatment and control groups, age of the groups and the impact of credit on income and productive asset created at the household level.

Impact of SHGs on Individual Income: The members of the SHGs are supposed to make use of small loans for productive activities, which would increase their income. To identify the increase in the level of income, as stated earlier we have created two groups; one for the households with SHG and the other with no participation in the program. The results from Table 1 explain the increase in income for the households that participated in the program. For instance, a closer look at the table 
explains average income of the members to be Rs.1492 after joining SHG compared to Rs.647 before joining SHG, i.e. income increased about 1.3 times. This increment in income is found to be 41 percent, 151 percent, 329 percent and 320 percent for the SHG members of Tiruvallur, Tiruttani, Gummudipoondi and Ponneri blocks respectively. It is clear from the analysis that the increased income is highest in case of Gummudipoondi and Ponneriblocks.

\begin{tabular}{lcccc}
\hline \multirow{2}{*}{ Clusters } & \multicolumn{4}{c}{ Average Income of the Respondents } \\
\cline { 2 - 5 } & Before membership & After membership & $\begin{array}{c}\text { Changes in income } \\
(\%)\end{array}$ & 't' value \\
\hline Tiruvallur & 1514 & 2148 & 41.87 & $4.49^{*}$ \\
\hline Tiruttani & 663 & 1670 & 151.89 & $6.64^{*}$ \\
\hline Gummudipoondi & 304 & 1243 & 329.93 & $8.26^{*}$ \\
\hline Ponneri & 253 & 1064 & 320.55 & $7.43^{*}$ \\
\hline Total & 647 & 1492 & 130.60 & $6.79^{*}$ \\
\hline
\end{tabular}

Table 1. Change in Income (in Rs)

Source: Computed from the Primary Data collected by the researcher in 2010.

Variations in Income of the SHG-Members and Non-SHG members: The income level of the members has been significantly greater compared to the non-members. The statistical analysis provided in Table 2 reveals that average income of the non-members is Rs.998 compared to Rs.1492 of the members of SHG. It proves that the income of the members has increased substantially. The average income of the members is 0.7 times higher than the average income of non-members. The percentage increase in the income of the members over the income of the non-members is the highest for Tiruvallur block, i.e. 80 percent followed by Tiruttani (77 percent), Gummudipoondi (19 percent) and Ponneri (29 percent) blocks.

\begin{tabular}{lcccc}
\hline \multirow{2}{*}{ Clusters } & \multicolumn{4}{c}{ Average Income } \\
\cline { 2 - 5 } & Control Group & Treatment Group & $\begin{array}{c}\text { Changes in income } \\
(\%)\end{array}$ & 't' value \\
\hline Tiruvallur & 1193 & 2148 & 80.05 & $7.24^{*}$ \\
\hline Tiruttani & 942 & 1670 & 77.28 & $6.82^{*}$ \\
\hline Gummudipoondi & 1042 & 1243 & 19.28 & $2.69^{*}$ \\
\hline Ponneri & 823 & 1064 & 29.28 & $4.98^{*}$ \\
\hline Total & 998 & 1492 & 49.49 & $5.97^{*}$ \\
\hline
\end{tabular}

Table 2. Income of the Members and Non-Members (per month)

Source: Computed from the Primary Data collected by the researcher in 2010. 
The fundamental principle of SHG is to nurture savings habit among poor households, so that savings is a compulsory component of SHG activities. The amount of savings may vary from member to member but every member should maintain a minimum of savings Rs. 25 per week. To verify whether income and savings are related we use the correlation coefficient between income and savings using the following approach:

$\sqrt{n}(\gamma-p) \Rightarrow N\left(0,\left(1-p^{2}\right) 2\right.$

under $H 0, \rho=0, \sqrt{n} \gamma \sim N(0,1)$

using, $\sqrt{n}\left(\frac{1}{2} \log \frac{1-r}{1+r}-\frac{1}{2} \log \frac{1-\rho}{1+\rho}\right) \Rightarrow N(0,1)$,

we obtain a $95 \%$ CI for $\rho$ as $(0.53,0.66)$.

The computed ' $r$ ' value is 0.60 that implies a positive correlation between savings and income. Therefore, if income potentials of a household increases there is a possibility of increase in the saving potential as well. As explained earlier, the income potentials of the SHG members are greater than that of the non-members. Therefore, we may conclude that the income and savings of the members are higher compared to the non-members due to the microfinance activities in the form of SHG participation.

Groups' Age on Income: As mentioned earlier, the SHGs are successfully linked with banks for credit after six months have successfully elapsed. The methodology adopted by the banks for credit provision to SHG is that a group can obtain a fresh loan once they successfully pay off the existing loans. In this context, the age of the group becomes an important parameter in getting a credit. Matured groups may have higher chances of obtaining credits than other groups. The banks are providing credit only for development and acquisition of productive assets. Along these lines, the age of a group plays a considerable role in escalating the earnings of the group members. In order to analyse the impact of group's age on the income of members, the SHGs are categorized into 3-5 years old (Young Groups); 5-7 years old (Middle Groups) and more than 7 years old (Matured Groups). Table 3 explains the income earned by the members of SHGs of Tiruvallur, Tiruttani, Ponneri and Gummudipoondi blocks according to the age of the group. The average increase in income after joining SHG is significant and highest for the members of the Matured Group followed by the Middle age and Young Group members. The addition to income, over the pre-SHGs situation for the Young, Middle age and Matured group members is noticed to be Rs.647, Rs.652 and Rs.609 per month for Tiruvallur Rs.905, Rs.1131 and Rs.963 for Tiruttani and Rs.888, Rs.856 and Rs.997 for Gummudipoondi and Rs.795, Rs.747 and Rs.1069 for Ponneri blocks, respectively. In addition, the analysis also reports that the addition of average income of the Young Group members after participating in the SHGs program is Rs.817 and with the Middle age Group members it is Rs.817, and with the Matured Group members it is Rs.897. It has also been established from the study that as a group age increases, the possibility of disposable income is higher. 


\begin{tabular}{|c|c|c|c|c|c|c|}
\hline Clusters & Group's Age & $\mathrm{N}$ & $\begin{array}{c}\text { Avg. income } \\
\text { pre-membership }\end{array}$ & $\begin{array}{c}\text { Avg. income } \\
\text { post-membership }\end{array}$ & $\begin{array}{l}\text { Changes in } \\
\text { income (\%) }\end{array}$ & 't' value \\
\hline \multirow{4}{*}{ Tiruvallur } & Young & 15 & 2186 & 2833 & 29.60 & $2.62^{\star}$ \\
\hline & Middle & 36 & 1281 & 1933 & 50.90 & $4.84^{\star}$ \\
\hline & Mature & 33 & 1462 & 2071 & 41.66 & $4.32^{\star}$ \\
\hline & Total & 84 & 1514 & 2148 & 41.88 & $4.49^{\star}$ \\
\hline \multirow{4}{*}{ Tiruttani } & Young & 20 & 745 & 1650 & 121.48 & $6.33^{*}$ \\
\hline & Middle & 29 & 517 & 1648 & 218.76 & $7.12^{\star}$ \\
\hline & Mature & 35 & 737 & 1700 & 130.66 & $6.31^{\star}$ \\
\hline & Total & 84 & 663 & 1670 & 151.89 & $6.64^{\star}$ \\
\hline \multirow{4}{*}{ Gummudipoondi } & Young & 25 & 372 & 1260 & 238.71 & $7.66^{*}$ \\
\hline & Middle & 16 & 162 & 1018 & 528.40 & $8.92^{*}$ \\
\hline & Mature & 44 & 318 & 1315 & 313.52 & $8.11^{\star}$ \\
\hline & Total & 85 & 304 & 1243 & 308.88 & $8.26^{\star}$ \\
\hline \multirow{4}{*}{ Ponneri } & Young & 44 & 345 & 1140 & 230.43 & $6.84^{\star}$ \\
\hline & Middle & 54 & 208 & 955 & 359.13 & $8.87^{\star}$ \\
\hline & Mature & 16 & 156 & 1225 & 685.26 & $8.96^{\star}$ \\
\hline & Total & 114 & 253 & 1064 & 320.55 & $7.43^{*}$ \\
\hline \multirow{4}{*}{ Total } & Young & 104 & 694 & 1511 & 117.72 & $6.23^{\star}$ \\
\hline & Middle & 135 & 555 & 1372 & 147.21 & $6.61^{\star}$ \\
\hline & Mature & 128 & 707 & 1604 & 126.87 & $6.04^{\star}$ \\
\hline & Total & 367 & 647 & 1492 & 130.60 & $6.79^{\star}$ \\
\hline
\end{tabular}

Table 3. Group's Age on Income of the Member (in Rs.) (per month)

Source: Computed from the Primary Data collected by the researcher in 2010.

Changes in Household Income: The SHGs programs boost up the individual's income, which subsequently add up to the total household's income. In some cases, SHGs activities are primary source of household income. The SHG members do invest their loans in income promoting activities i.e. starting-up a new business or expanding their existing business, which leads to the generation of income, enables the members to support their families in a better way. The household monthly income of the members and the non-members is shown in Table 4. The table reflects that the increase in the household income is the highest in Tiruttani block ( 81 percent) followed by Tiruvallur (62 percent) and Ponneri (29 percent) blocks. The average household income of the members is Rs. 5539 which is higher than that of the non-members by 41 percent i.e. Rs.1614. The SHGs programs enable the beneficiaries to better contribute to their household revenue. Table 5 shows the level of income of both member and non-member households. The table reveals that the majority of the member households, i.e. 37.05 percent belong to the income group of Rs. 4,000-6,000 per month, whereas the majority of the nonmembers i.e. 62.35 per cent fall into the income group of Rs. 2,000-4,000 per month. 4.35 percent of the members' and 4.49 percent of the non-members' household income drops below Rs. 2,000. The study underscored that 32.15 percent of the member households earn above Rs. 6,000 per month compared 
to 6.18 percent of the non-member households. It is crystal clear from the analysis that the household income level of the members is higher than that of the non-members.

\begin{tabular}{lcccc}
\hline \multirow{2}{*}{ Blocks } & \multicolumn{4}{c}{ Household's Income (in Rs) } \\
\cline { 2 - 5 } & Treatment Group & Control Group & Increment (\%) & 't' value \\
\hline Tiruvallur & 5942 & 3668 & 38.27 & $3.82^{*}$ \\
\hline Tiruttani & 5848 & 3217 & 44.99 & $2.69^{*}$ \\
\hline Gummudipoondi & 5067 & 4180 & 17.51 & $5.23^{*}$ \\
\hline Ponneri & 5368 & 4155 & 22.60 & $4.21^{*}$ \\
\hline Total & 5539 & 3925 & 29.14 & $5.11^{*}$ \\
\hline
\end{tabular}

Table 4. Household Income of the Treatment Group and Control Group (per month)

Source: Computed from the Primary Data collected by the researcher in 2010.

\begin{tabular}{lcccccccccc}
\hline $\begin{array}{c}\text { Income level } \\
\begin{array}{c}\text { (In Rs.) } \\
\text { (per month) }\end{array}\end{array}$ & \multicolumn{4}{c}{ Treatment Group (in numbers) } & \multicolumn{5}{c}{ Control Group (in numbers) } \\
\cline { 2 - 13 } & Villi & Minj & GP & Ponneri & Total & Villi & Minj & GP & Ponneri & Total \\
\hline$>$ Rs.2000 & 4 & 2 & 7 & 3 & 16 & 3 & 1 & 1 & 3 & 8 \\
\hline Rs.2000-4000 & 25 & 18 & 25 & 29 & 97 & 33 & 17 & 28 & 33 & 111 \\
\hline Rs.4000-6000 & 21 & 35 & 25 & 55 & 136 & 9 & 2 & 16 & 21 & 48 \\
\hline Rs.6000-8000 & 18 & 17 & 22 & 19 & 76 & 3 & - & 5 & 3 & 11 \\
\hline Rs.8000-10000 & 11 & 9 & 4 & 5 & 29 & 0 & 0 & 0 & 0 & 0 \\
\hline$<$ Rs.10000 & 5 & 3 & 2 & 3 & 13 & 0 & 0 & 0 & 0 & 0 \\
\hline Total & 84 & 84 & 85 & 114 & 367 & 48 & 2 & 50 & 60 & 178 \\
\hline
\end{tabular}

Table 5. Household Income classification

Source: Computed from the Primary Data collected by the researcher in 2010.

This statistical analysis confirms that the income and saving potential of the household that are participating in the programme are better off compared to the non-members. Furthermore, involvement in the program for a longer time allows members to get higher loans, and hence increases their income at a household level. In addition, all sections of the society benefitted by this program. Therefore the next step in this analysis is to examine the impact of SHGs credit on outcomes related to income and asset which is explained in the next section.

\section{Impact of SHGs loans on Income and Assets}

The study has applied simultaneous equation models to determine the impacts of borrowing on income and assets using two-stage least square (2SLS) estimation system of equation as follows: 
$C_{i j}=\propto+\beta_{c} X_{i j}+\gamma_{c} V_{i j}+\pi Z_{i j}+\varepsilon_{i j}{ }^{c}$

$y_{i j}=\propto+\beta_{y} X_{i j}+\gamma_{y} V_{i j}+\delta C_{i j}+\varepsilon_{i j}^{y}$

$\mathrm{X}_{\mathrm{ij}}$ - Vector of the exogenous household characteristics

$\mathrm{V}_{\mathrm{ij}}$ - Vector of the village infrastructure characteristics

$\mathrm{Z}_{\mathrm{ij}}$-Vector set of the household or Village characteristics that affect Cij

$\beta_{c}, \gamma_{c}, \beta_{y}, \gamma_{y}$ and $\delta$ - Unknown parameters

$\sum_{i j}^{c}, \sum_{i j}^{y}-$ Random Errors

The above equation indicates that the amount of borrowing loan is a function of household characteristics, village specific and other related variables. Furthermore, the next empirical specification shows that the dependent variable depends on the same village specific, demographic and also amount of borrowing.

Table 6 displays the number of household outcomes being the function of amount of borrowing, age related characteristics, education, gender and village household. In the following cases, income and assets are taken as the major explained variables of the model, mostly taken as a proxy for the household outcomes in two different specifications. Our empirical estimates show that households play a crucial role in determining the level of borrowing compared to the income. Our empirical estimate shows that every $1 \%$ increase in borrowing leads to $1.94 \%$ increase in household assets, compared to the $0.95 \%$ increase in borrowing rate out of income source (see columns I and II). Furthermore, we find positive impact of age, education and gender of the household in determining the income level (Table 6, row 3 \& 4). It implies that incomes of households are affected positively by the amount of credit. In order to examine the effect of age, we further examined the equation using age-square. The study has shown negative and significant coefficient of age-square, implying that as age increases, income of household also increases but at a certain level it starts dropping. We discovered that there is a positive coefficient of education level of the respondents. Thus, it is beneficial to gain more education. The study has found that most households are headed by male and the estimation shows that the male headed households have a larger income for the family.

Table 7 shows 2SLS estimation result of simultaneous equation model using asset as one of the dependent variables. In this model, the researcher has used log transformed assets and credit for estimation. The study has found that SHGs credit makes changes in the household assets significantly to enhance household assets. Positive coefficient of age shows that as age increases household assets also increase. It can also be concluded that education contributes to a better quality of life through enhancing household possessions. Gender of household head is also found to be positive and significant. The positive and significant coefficient of village infrastructure implies that better infrastructure of the village may facilitate household assets. 


\begin{tabular}{|c|c|c|}
\hline \multirow{2}{*}{ Variables } & \multicolumn{2}{|c|}{ Log of income } \\
\hline & Equation-1 & Equation-2 \\
\hline \multirow{2}{*}{ Intercept } & $4.34^{* *}$ & $3.73^{* * *}$ \\
\hline & $(2.58)$ & $(2.12)$ \\
\hline \multirow{2}{*}{ Log of Amount of borrowing } & $0.94^{\star *}$ & $1.93^{* * *}$ \\
\hline & $(3.74)$ & $(3.66)$ \\
\hline \multirow{2}{*}{ Age } & $0.50^{* * *}$ & \\
\hline & $(2.07)$ & - \\
\hline \multirow{2}{*}{ Age- squared } & $-0.28^{* * *}$ & \\
\hline & $(-2.58)$ & . \\
\hline \multirow{2}{*}{ Education } & $0.48^{*}$ & \\
\hline & $(1.92)$ & 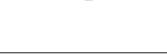 \\
\hline \multirow{2}{*}{ Gender of the household } & $0.61^{* * *}$ & 0.29 \\
\hline & $(4.87)$ & $(3.41)$ \\
\hline \multirow{2}{*}{ Proportionate of male in the Family Size } & 0.001 & -0.001 \\
\hline & $(-0.73)$ & $(-0.71)$ \\
\hline \multirow{2}{*}{ Village infrastructure } & -0.03 & 0.008 \\
\hline & $(-0.62)$ & $(0.16)$ \\
\hline R-sq & 0.25 & 0.14 \\
\hline \multirow{2}{*}{$\begin{array}{l}\text { F value } \\
\text { Prob }>\text { F }\end{array}$} & 23.33 & 22.14 \\
\hline & $(0.00)$ & $(0.00)$ \\
\hline Sample Size & 367 & 367 \\
\hline
\end{tabular}

Table 6. Estimation of Amount of loans borrowing on Household Outcome: Log of Income

Source: Computed from the Primary Data collected by the researcher in 2010.

\section{CONCLUDING OBSERVATIONS}

The results illustrate that microfinance has significantly improved the living standards of the members in general and the female members in particular. The study highlights that a significant proportion of the SHG members have increased the income potential in the post SHG participation. The benefit of enrollment in the SHG program is directly linked with income generation, savings potential and ability to borrow loans from the SHGs. Microfinance in the form of SHG has also helped different age classification of the sample, therefore the positive impact of the program is that it is equally beneficial for different age groups. Credits from the SHG have also helped households to arrive at productive asset, which can be used by the household for any immediate purpose. Educated households are better at achieving higher benefits of the program. The study concludes that female headed households also benefit from the program and it makes them independent, in the long run these kinds of programs reduce a gender gap in employment and income generating activities. Therefore, to eradicate poverty and make a sustainable development for the underprivileged section of the society, microfinance (SHG) can be a better policy instrument along with a program related to improving higher education at a village level. 


\begin{tabular}{lcc}
\hline \multirow{2}{*}{ Variable (s) } & \multicolumn{2}{c}{ Log of Assets } \\
\cline { 2 - 3 } Intercept & Equation-1 & Equation-2 \\
& $-3.73^{* *}$ & -7.30 \\
\hline \multirow{2}{*}{ Log of amount of borrowing } & $(-2.12)$ & $(-1.68)$ \\
\hline \multirow{2}{*}{ Age } & $1.42^{* * *}$ & $1.52^{* *}$ \\
\cline { 2 - 3 } & $(2.72)$ & $(2.74)$ \\
Education & $0.01^{* *}$ & - \\
\hline \multirow{2}{*}{ Gender of Household } & $(2.05)$ & - \\
\hline \multirow{2}{*}{ Proportion of male in family size } & $0.02^{* *}$ & $0.48^{*}$ \\
\hline Village infrastructure & $(2.28)$ & $(1.69)$ \\
\hline R-sq & 0.41 & 0.003 \\
\hline F value & $(1.72)$ & $(0.54)$ \\
Prob> F & 0.003 & -0.07 \\
\hline Sample Size & $(0.52)$ & $(-0.52)$ \\
\hline
\end{tabular}

Table 7. Estimation of Amount of loans borrowing on Household outcome: Log of Assets Source: Computed from the Primary Data collected by the researcher in 2010.

\section{REFERENCES}

Armendáriz, B., \& Morduch, J. (2005). The economics of microfinance. MIT Press: Cambridge, MA.

Copestake et al. (2005). Monitoring the diversity of the poverty outreach and impact of microfinance: A comparison of methods using data from Peru. Development Policy Review, 23 (6), 703-23. DOI: 10.1111/j.14677679.2005.00309.x.

Copestake, J. (2002). Poverty, inequality and the polarising impact of microcredit: evidence from Zambia’s Copperbelt. Journal of International Development, 14(6), 743-755. DOI: 10.1002/jid.921.

Cull, R., Demirgüc-Kunt, A., \& Morduch, J. (2009). Microfinance meets the market. Journal of Economic Perspectives, 23(1), 167-192. DOI: 10.1257/jep.23.1.167.

Deloach, S. B., \& Lamanna, E. (2011). Measuring the Impact of Microfinance on Child Health Outcomes in Indonesia. World Development, 39(10), 1808-1819. DOI: 10.1016/j.worlddev.2011.04.009.

Dichter, T., \& Malcolm, H. (2007) What's wrong with Microfinance? London: Practical Action Publishers.

Dunford, C. (2006). Evidence of microfinance's contribution to achieving the millennium development goals. Retrieved May 5, 2017, from http://communitywealth.org/sites/clone.community-wealth.org/files/downloads/ paper-dumford.pdf.

Earne, J., \& Sherk, J. (2013). Funding. In J. Ledgerwood (Ed.), The new microfinance handbook (pp. 379-412). Washington, DC: The World Bank.

Fuchs, Z. (2006). Microfinance beyond philanthropy. Euromoney, 394-396. 
Galab, S., \& N. Chandrasekhar Rao. (2003). Women's Self-Help Groups, Poverty Alleviation and Women Empowerment. Economic \& Political Weekly, 38(12/13), 1274-1283.

Garikipati, S. (2012). Microcredit and women's empowerment: through the lens of time use data from rural India. Development and Change, 43(3), 719-750. DOI: 10.1111/j.1467-7660.2012.01780.x.

Gertler, P., Levine, D., \& Moretti, E. (2006). Do Microfinance Programs Help Families Insure Consumption Against Illness? Health Economics, 18(3):257-73. DOI: 10.1002/hec.1372.

Goetz, A.M., \& Sen Gupta, R. (1996). Who takes the credit? Gender, power and control over loan use in rural credit programmes in Bangladesh. World Development, 24(1), 45-63. DOI: 10.1016/0305-750X(95)00124-U.

Hashemi, S., Schuler, S. R., \& Riley, A. (1996). Rural credit programs and women's empowerment in Bangladesh. World Development, 24, 635-653.

Hazarkia, G. \& Sarangi, S. (2008). Household Access to Microcredit and Child Work in Rural Malawi. World Development, 24(4), 635-653. DOI: 10.1016/0305-750X(95)00159-A.

Hulme, D., \& Mosley, P. (1996). Finance against Poverty. London: Routledge.

Jacobsen, G. (2009). Health and Death Risk and Income Decisions: Evidence from Microfinance. Journal of Development Studies, 45, 934-946.

Khandker, S.R. (2005). Microfinance and poverty: Evidence using panel data from Bangladesh. The World Bank Economic Review, 19(2), 263-86.

Kouassi, M.J. (2008). Microfinance and Health: A Study of Selected Countries. Ph.D., Howard University.

Leatherman. S., Metcalfe, M., Geissler, K., \& Duford, C. (2012). Integrating Microfinance and Health Strategies: Examining the Evidence to Inform Policy and Practice. Health Policy and Planning, 27(2), 85-101. DOI: 10.1093/heapol/czr014.

Ledgerwood, J., \& Gibson, A. (2013). The evolving financial landscape. In J. Ledgerwood (Ed.), The new microfinance handbook: a financial market system perspective. Washington, DC: World Bank.

Maes, J., \& Reed, L. (2012). State of the microcredit summit campaign report 2012. Washington, DC: Microcredit Summit Campaign.

Morduch, J. (1999). The microfinance promise. Journal of Economic Literature, 37(4), 1569-1614. DOI: 10.1257/ jel.37.4.1569.

NABARD. (1999). Task Force on Supportive Policy and Regulatory Framework for Micro Finance: Summary and Recommendations. Retrieved May 5, 2017, from http://www.gdrc.org/icm/country/india-mftaskforce.html.

Pitt, M. M., \& Khandker, S.R. (1998). The impact of group-based credit programs on poor households in Bangladesh: Does the gender of participants matter? Journal of Political Economy, 106(5), 958-96.

Pitt, M.M., Khandker, J., \& Cartwright, J. (2006). Empowering Women with Micro Finance: Evidence from Bangladesh. Economic Development and Cultural Change, 54 (4), 791-831.

Rahman, S., Junankar, P. N., \& Mallik, G. (2009). Factors influencing women's empowerment on microcredit borrowers: a case study in Bangladesh. Journal of the Asia Pacific Economy, 14(3), 287-303. DOI: 10.1080 /13547860902975648.

Saravanan, S., \& Dash, D. P. (2017). Microfinance and Women Empowerment- Empirical Evidence from the Indian States. Regional and Sectoral Economic Studies, 17-2(2017),61-74.

Simanowitz, A. \& Walter, A. (2002). Ensuring Impact: Reaching the Poorest while Building Financially SelfSufficient Institutions, and Showing Improvement in the Lives of the Poorest Women and Their Families. In Sam Daley-Harris, Ed. Microcredit Summit Campaign. Pathways Out of Poverty. Kumarian: Bloomfield, CT.

Steele, F., Amin, S., \& Naved, R. (1998). The Impact of an Integrated Micro-credit Program on Women's Empowerment and Fertility Behavior in Rural Bangladesh. Population Council Policy Research Division Working Paper No. 115. Retrieved May 5, 2017, from www.popline.org/node/279519.

Tedeschi, G. (2010). Microfinance: Assessing Its Impact on Microenterprises. In: Munoz, J. M. S. (Ed.) Contemporary Microenterprise: Concepts and Cases. Cheltenham : Edward Elgar. 
Chiu, TK. (2017). Factors Influencing Microfinance Engagements by Formal Financial Institutions. Journal of Business Ethics, 143(3). 565-587. DOI: 10.1007/s10551-015-2811-1.

Van Rooyen, C., Stewart, R., de Wet, T. (2012). The impact of microfinance in Sub-Saharan Africa: A systematic review of the evidence. World Development, 40(11). 2249-2262. DOI: 10.1016/j.worlddev.2012.03.012.

World Bank. (2016). India's Poverty Profile. Retrieved May 5, 2017, from www.worldbank.org/en/news/infographic/2016/05/27/india-s-poverty-profile.

\section{DA LI PROGRAM GRUPE SAMOISPOMOĆI (SHG) SMANJUJE SIROMAŠTVO NA PRIMERU ČETIRI GRUPE IZ POLUURBANIH PODRUČJA INDIJE?}

\section{Rezime:}

U ovom radu se izražava mišljenje da program mikrofinansija značajno pobolǰ̌ava životni standard siromašnih. Podaci su uzeti u analizu na osnovu uzorka od 367 članova Programa grupe samoispomoći, kao i 178 pripadnika koji to nisu. Metod simultane jednačine je primenjen u cilju analize efekta egzogenih varijabli na endogenu varijablu. Dohodak i imovina su endogene varijable koje imaju značajan uticaj jedna na drugu. Uzrast, stepen obrazovanja i seoska infrastruktura imaju pozitivan uticaj i na dohodak i na imovinu.

Ključne reči:

siromaštvo, mikrofinansije, kontrola, tretiranje, simultane jednačine. 